\title{
ECONOMIC REFORM AND CROSS-STRAIT RELATIONS
}

Taiwan and China in the WTO 
This page intentionally left blank 


\title{
Series on Contemporary China - Vol. 9 \\ ECONOMIC REFORM AND CROSS-STRAIT RELATIONS
}

Taiwan and China in the WTO

\author{
editors \\ Julian Chang \\ Harvard University, USA \\ Steven M. Goldstein \\ Smith College, USA
}




\section{Published by}

World Scientific Publishing Co. Pte. Ltd.

5 Toh Tuck Link, Singapore 596224

USA office: 27 Warren Street, Suite 401-402, Hackensack, NJ 07601

UK office: 57 Shelton Street, Covent Garden, London WC2H 9HE

\section{British Library Cataloguing-in-Publication Data}

A catalogue record for this book is available from the British Library.

\section{Series on Contemporary China - Vol. 9 \\ ECONOMIC REFORM AND CROSS-STRAIT RELATIONS \\ Taiwan and China in the WTO}

Copyright ( 2007 by World Scientific Publishing Co. Pte. Ltd.

All rights reserved. This book, or parts thereof, may not be reproduced in any form or by any means, electronic or mechanical, including photocopying, recording or any information storage and retrieval system now known or to be invented, without written permission from the Publisher.

For photocopying of material in this volume, please pay a copying fee through the Copyright Clearance Center, Inc., 222 Rosewood Drive, Danvers, MA 01923, USA. In this case permission to photocopy is not required from the publisher.

ISBN-13 978-981-256-854-0

ISBN-10 981-256-854-9

Typeset by Stallion Press

Email: enquiries@stallionpress.com

Printed in Singapore. 


\section{Contents}

List of Tables . . . . . . . . . . . . . . . . . . . . . . vii List of Figures. . . . . . . . . . . . . . . . . . . . xi Acknowledgements ..................... xiii

1. Introduction: The WTO and Cross-Strait Economic Relations . . . . . . . . . . . . . . . . . . . . . 1 Julian Chang and Steven M. Goldstein

2. WTO Commitments by Taiwan and China and the Domestic Consequences . . . . . . . . . . . . . . 43 Tain-Jy Chen

3. The Legal and Political Implications of Taiwan's WTO Accession . . . . . . . . . . . . . . . . . . . . .73 Connie Guang-Hwa Yang

4. Economic Prospects from Cross-Strait WTO Membership . . . 119 Chi Schive 
vi Contents

5. Taiwan's Role in the Economic Architecture of East Asia and the Pacific . . . . . . . . . . . . . . . . . . . . . . 149 Peter Drysdale and Xinpeng Xu

6. The Political Economy of Cross-Strait Relations: Economic Interdependence, the WTO, and Security . . . . . . . . . . 187 Joseph Fewsmith

7. The Challenges and Opportunities for Taiwan and China in the Financial Sector after Entry into the WTO . . . . . . . . . . . . . . . . . . . . . . . 209 Jib-chu Lee

8. WTO Accession and its Implications for Agriculture in Taiwan and China . . . . . . . . . . . . . . . . . . . 237 Robert Ash

9. The Impact of the WTO on Taiwan's and China's Electronics Industries. . . . . . . . . . . . . . . . . . . . . 285 Charles Trappey

10. The Impact of Accession to the WTO: The Case of the Automobile Industry . . . . . . . . . . . . . . . . . . . . 319 Chwo-Ming Joseph Yu

11. Postscript . . . . . . . . . . . . . . . . . . . . . 357 Steven M. Goldstein

Index . . . . . . . . . . . . . . . . . . . . . . . . . . . . . . .363 


\section{List of Tables}

Table 2.1 Automobile Imports to Taiwan, $2002 \ldots \ldots$. . . . . 58

Table 2.2 Distribution of Quota Allocations among

Japanese Car Manufacturers, 2003 . . . . . . . . . . . 59

Table 4.1 Impact of Taiwan and PRC WTO Entry (Static Simulation) . . . . . . . . . . . . . . . 120

Table 4.2 Trade before and after WTO Accession . . . . . . . . 124

Table 4.3 Permitted Items for Import from the PRC, by Chinese Classification of Commodities, February 2004 . . . . . . . . . . . . . . . . . . . . 130

Table 4.4 Commodities Prohibited from Importing from the PRC (July 2003) . . . . . . . . . . . . . . . . 131

Table 4.5 Sectors Permitted for PRC Investment . . . . . . . . . . 134

Table 4.6 Prohibited Sectors for PRC Investment . . . . . . . . . 137

Table 4.7 Prohibited Areas for Investment and Technical Collaboration with the PRC . . . . . . . . . . . . 139 
viii List of Tables

Table 5.1 China's Top Sources of Foreign Investment (cumulative FDI) to 2003 . . . . . . . . . . . . . . . 153

Table 5.2 China: Changing Structure of FDI Inflows (percent)

Table 5.3 China and East Asia: Share in World Exports (percent) . . . . . . . . . . . . . . . 156

Table 5.4 Trade across the Taiwan Strait (US\$ billlion) . . . . . 157

Table 5.5 Taiwan: Geographic Structure of Exports (percent) . . . . . . . . . . . . . . . . . 158

Table 5.6 Taiwan: Geographic Structure of Imports (percent) . . . . . . . . . . . . . . . . . . . . . 159

Table 5.7 China, South Korea, and Taiwan: Trade Complementarity, Bias, and Intensity Indexes 164

Table 7.1 Asset Market Share of the Top Five Banks in Taiwan Compared with Counterparts in Other Asian Countries . . . . . . . . . . . . . . . . . . . 213

Table 7.2 Average Asset Scale of the Top Five Banks in Taiwan Compared with Regional and Global Counterparts

Table 7.3 The NPL Ratio of Taiwan's Banking Sector (Unit: \%) . . . . . . . . . . . . . . . . . . . . . . . 214

Table 7.4 Profit Comparison between Domestic and Foreign Banks in Taiwan (Unit: \%) . . . . . . . . . . . . 214

Table 7.5 A Comparison of Revenue Sources of Domestic and Foreign Banks in Taiwan (Unit: \%) . . . . . . . . . 215

Table 7.6 The NPL Ratio of Taiwan's Banks . . . . . . . . . . . . . . 218 Table 7.7 The Market Share of the Big-Four State-owned Banks . . . . . . . . . . . . . . . . . . . . 221

Table 7.8 Acquisition of Chinese Banks by Foreign Banks in Recent Years . . . . . . . . . . . . . . . . . . . 225

Table 7.9 Mainland China's Specific Commitments on Liberalization of the Financial Sectors for the Hong Kong CEPA. 
Table 8.1 The WTO Framework Agreement: Major Provisions Affecting Taiwan's Agriculture . . . . . . . . 240

Table 8.2 The WTO Framework Agreement and China's Agriculture . . . . . . . . . . . . . . . . . 241

Table 8.3 Changes in Grain Cultivation, 1990-2001 . . . . . . . . 251

Table 8.4 Net Exports of Animals, Vegetables, Fruit, Aquatic Products, and Cured Tobacco . . . . . . . . . 257

Table 8.5 Employment in Agriculture (Crop Farming, Forestry, Fishing, and Husbandry) . . . . . . . . . . 260

Table 8.6 The Declining Contribution and Changing Composition of Agriculture in Taiwan . . . . . . . . . . 262

Table 8.7 Rice Production in Taiwan . . . . . . . . . . . . . . . . 268 Table 8.8 The Changing Profile of Farm Production in Taiwan (1995-2003) . . . . . . . . . . . . . . . . 270

Table 8.9 Taiwan's Agricultural Foreign Trade . . . . . . . . . . . . 272

Table 8.10 Taiwan's Agricultural Trade Balance . . . . . . . . . . . 273

Table 8.11 Exports of Agricultural Products from Taiwan to Japan, the U.S., Hong Kong, and China . . . . . . . 280 Table 8.12 Imports of Agricultural Products from the U.S., Australia, Japan, Thailand, and China . . . . . . 282

Table 10.1 The Major Automakers . . . . . . . . . . . . . . . . . . 321 Table 10.2 Dominant Joint Ventures in China's Auto Industry . . . . . . . . . . . . . . . . . . 326

Table 10.3 Market Size in Taiwan . . . . . . . . . . . . . . . . 328

Table 10.4 Profiles of Automakers in Taiwan . . . . . . . . . . . 330

Table 10.5 Simulation Design . . . . . . . . . . . . . . . . 343

Table 10.6 Simulation Results for the Motor

Vehicle Sector (Unit: \%) . . . . . . . . . . . . . . . . . . 343 
This page intentionally left blank 
Figure 5.1 China and East Asia in the world economy:

Output share valued at PPP (percent) . . . . . . . . 151

Figure 5.2 China and East Asia in the world economy:

Output share valued at market

exchange rates (percent) . . . . . . . . . . . . . . 152

Figure 5.3 Taiwan's investment in mainland

China (US\$ million) . . . . . . . . . . . . . . . . . . 177

Figure 9.1 Taiwan's development of a comprehensive semiconductor supply chain . . . . . . . . . . . . . 297

Figure 9.2 Approved indirect mainland electronic and electronic appliance investment from Taiwan (US\$ 1,000) . . . . . . . . . . . . . . . . . 300

Figure 9.3 Electronics investment is encouraged by the sectoral guidance catalog and electronics dumping issues are covered by a Joint Task Force of the MOFCOM and the SETC . . . . . . . . 306 
xii List of Figures

Figure 9.4 Uplifting import values to match reference prices in Article VII . . . . . . . . . . . . 308

Figure 10.1 Joint ventures of First Automobile Works Group . . . . . . . . . . . . . . . 334

Figure 10.2 Joint ventures of Shanghai Automotive Industry Corporation . . . . . . . . . . . . . 336

Figure 10.3 Joint ventures of Dongfeng Motors Corporation . . . . . . . . . . . . . 337

Figure 10.4 Other joint ventures . . . . . . . . . . . . . 338

Figure 10.5 Value chain of the automobile industry . . . . . . . 351

Figure 10.6 Relationships among automakers . . . . . . . . . . 355 


\section{Acknowledgements}

Our thanks go first to the authors of the chapters that follow for their efforts and their patience, as this project found its way to conclusion.

This project was supported by a grant from the Ministry of Foreign Affairs of the Republic of China.

Steven Goldstein would like to thank Maja Gray and Christa Daly for their research assistance. In addition, thanks go to the Chiang Ching-kuo International Foundation for its support for the research on Taiwan.

Julian Chang would like to thank Dimitre Michev for his research assistance at an early stage of this project.

And lastly, we are indebted to Nancy Hearst for doing her usual editorial magic on this manuscript. We, like so many others in the field of Chinese studies, are fortunate to have benefited from her wisdom and skill. 